\title{
MAP1LC3A wt Allele
}

National Cancer Institute

\section{Source}

National Cancer Institute. MAP1LC3A wt Allele. NCI Thesaurus. Code C104612.

Human MAP1LC3A wild-type allele is located in the vicinity of 20q11.22 and is approximately $13 \mathrm{~kb}$ in length. This allele, which encodes microtubule-associated proteins 1A/1B light chain 3A protein, is involved in microtubule function and autophagocytosis. 